\title{
ASUPAN LEMAK DAN SERAT DENGAN KADAR TRIGLISERIDA PADA PASIEN DIABETES MELLITUS TIPE II
}

\author{
Fitri Apriyani, Emy Yuliantini, Darwis \\ Politeknik Kesehatan Kementerian Kesehatan Bengkulu, Jurusan Gizi, \\ Jalan Indragiri Nomor 03 Padang Harapan Kota Bengkulu \\ emyardi08@yahoo.com
}

\begin{abstract}
Diabetes mellitus is a disease that can be prevented by lifestyle changes such efforts diet. Where should limit your intake of fat and fiber intake multiply. The purpose of this study was to determine the relationship of fat and fiber intake with triglyceride levels in patients with diabetes mellitus type II in Internal Medicine Poly General Hospital Dr. M. Yunus Bengkulu. The method used in the case-control study using a retrospective approach. Sampling was purposive sampling by the sampling is done by taking the patient or respondent in accordance with the specified criteria researchers. Univariate analysis using statistical methods and analysis using the Bivariate Correlation. The results showed that there was significant correlation with $p=0.002>0.05$, the variable fat intake with triglyceride levels in patients diabetes mellitus type II in Internal Medicine Poly General Hospital Dr M Yunus Bengkulu, and no significant relationship with the variable fiber intake with triglyceride levels of $\mathrm{p}=0.183>0.05$ in patients diabetes mellitus type II in Internal Medicine Poly General Hospital Dr M Yunus Bengkulu.
\end{abstract}

Keywords: Intake of fat, Fiber, Triglyceride level, Patients DM

\begin{abstract}
ABSTRAK : Diabetes mellitus adalah suatu penyakit yang dapat dicegah dengan upaya perubahan gaya hidup seperti pola makan. Dimana harus membatasi asupan lemak dan perbanyak asupan serat. Tujuan penelitian untuk mengetahui hubungan asupan lemak dan serat dengan kadar trigliserida pada pasien diabetes mellitus tipe II di Poli Penyakit Dalam RSUD Dr. M. Yunus Bengkulu. Desain penelitian menggunakan case control dengan menggunakan pendekatan retrospective. Pengambilan sampel dengan cara Purposive sampling yaitu pengambilan sampel dilakukan dengan mengambil pasien atau responden yang sesuai dengan kriteria yang ditentukan peneliti. Analisa Univariat menggunakan metode statistik dan analisa Bivariat menggunakan Korelasi. Hasil penelitian pada pasien diabetes mellitus tipe II di Poli Penyakit Dalam RSUD Dr. M. Yunus Bengkulu menunjukan adanya hubungan yang bermakna antara asupan lemak dengan kadar trigliserida $(\mathrm{p}=0.002<0.05)$ namun asupan serat tidak berhubungan signifikan dengan kadar trigliserida $(\mathrm{p}=0.183>0.05)$.
\end{abstract}

Kata Kunci : Asupan Lemak, Serat, dan Kadar Trigliserida, Pasien DM

Meningkatnya kesadaran masyarakat akan pentingnya hidup sehat mengakibatkan tuntutan konsumen terhadap bahan juga semakin bergeser. Bahan pangan yang kini mulai banyak diminati konsumen bukan saja yang mempunyai komposisi gizi yang baik serta penampakan dan cita rasa yang menarik, tetapi juga harus memiliki fungsi fisiologis tertentu bagi tubuh (Astawa dan Tuti, 2004). Perubahan pola makan serba instan, tinggi lemak, banyak mengandung gula dan protein, ditambah kurangnya olahraga merupakan pemicu timbulnya berbagai penyakit, sa- lah satunya adalah diabetes mellitus. Diabetes mellitus adalah suatu sindroma gangguan metabolism dengan hiperglikemia yang tidak semestinya sebagai akibat suatu defisiensi sekresi insulin atau berkurangnya efektivitas biologis dari insulin (Greenspan et al., 2002)

Penyakit diabetes mellitus merupakan penyakit yang masih menjadi masalah kesehatan masyarakat. Angka morbiditas dan mortalitas dari penderita diabetes mellitus semakin hari semakin meningkat karena penyakit ini bersifat kronis, ditandai dengan 
gangguan metabolisme karbohidrat yang disertai juga gangguan metabolism lemak dan protein (Askandar, 2002).

Diabetes mellitus penyebab kematian ketiga diantara penyakit tidak menular terbesar di dunia, setelah penyakit kardiovaskuler dan kanker. WHO memperkirakan pada tahun 2000 jumlah penderita diabetes diatas umur 20 tahun berjumlah 150 juta orang dan dalam kurun waktu 25 tahun kemudian, pada tahun 2025, jumlah itu akan membengkak menjadi 300 juta orang (Suyono, 2009). Menurut Powers (2005) kejadian diabetes melitus meningkat seiring bertambahnya usia. Pada tahun 2000, prevalensi diabetes mellitus di dunia diperkirakan sebesar $0,19 \%$ pada orang usia $<20$ tahun dan 8,6\% pada orang usia $>20$ tahun. Pada orang usia $>65$ tahun prevalensi diabetes mellitus sebesar 20,1\%. Di tahun 2004 sekitar 3,4 juta orang meninggal akibat konsekuensi dari tingginya kadar gula darah pada orang yang menderita diabetes mellitus dan lebih dari $80 \%$ kematian tersebut terjadi di negara-negara dengan pendapatan menengah ke bawah (WHO, 2011).

Berdasarkan pola pertambahan penduduk saat ini diperkirakan jumlah penderita diabetes mellitus di dunia tahun 2010 sebanyak 306 juta, di Negara-negara ASEAN 19,4 juta pada tahun 2010 dan Indonesia pada tahun 2000 berjumlah 8,43 juta jiwa dan diperkirakan pada tahun 2030 mencapai 21,3 juta orang. Jumlah penderita diabetes mellitus menurut data WHO (World Health Organization), Indonesia menempati urutan ke-4 terbesar di dunia setelah China, India dan Amerika Serikat (Departemen Kesehatan, 2001).

Hasil Riset kesehatan Dasar (Riskesdas) tahun 2007, diperoleh proporsi penyebab kematian akibat diabetes mellitus pada kelompok usia 45-54 tahun di daerah perkotaan menduduki ranking ke-2 yaitu 14,7\%. Dan daerah pedesaan, DM menduduki ranking ke-6 yaitu 5,8\% (Depkes, 2009).

Rumah Sakit Umum Daerah Dr. M. Yunus Bengkulu pada tahun 2010 kasus diabetes mellitus berjumlah 3306 orang dengan jumlah kasus baru 173 orang terdiri dari laki- laki 85 orang, perempuan 88 orang. Pada tahun 2011 berjumlah 3330 orang dengan kasus baru 179 terdiri dari 79 orang laki-laki dan 100 orang perempuan. Sedangkan pada tahun 2012 dalam Triwulan ke III dengan jumlah 340 orang dengan kasus baru 185 . Data ini menunjukkan adanya peningkatan jumlah pasien penderita diabetes mellitus dari tahun ke tahun.

Diabetes mellitus adalah penyakit metabolik yang ditandai dengan meningkatnya kadar gula (glukosa) dalam darah yang di atas ambang normal. Salah satu penyebabnya selain asupan glukosa yang berlebih, dapat juga disebabkan oleh adanya resistensi insulin. Kasus resistensi insulin ini dapat kita temukan pada diabetes mellitus tipe II (Suyono, 1996).

Resistensi Insulin adalah kondisi dimana jumlah normal insulin tidak memadai untuk menghasilkan respons insulin normal dari sel lemak, sel otot dan sel hati. Resistensi insulin pada sel-sel lemak mengurangi efek insulin dan mengakibatkan peningkatan hidrolisis cadangan trigliserida. Sehingga pada diabetes mellitus, penurunan sensitivitas terhadap insulin dapat menyebabkan peningkatan trigliserida dalam darah (Suyono, 1996).

Trigliserida merupakan lemak netral yang masing-masing terdiri dari kombinasi gliserol dengan tiga molekul asam lemak melekat padanya. Trigliserida berperan dalam pengangkutan serta penyimpanan lipid. Selama pencernaan, dua molekul asam lemak dipisahkan, meninggalkan sebuah monogliserol, satu molekul gliserol dengan satu molekul asam lemak melekat padanya. Hasil cerna tersebut merupakan satuan lemak yang dapat diserap oleh tubuh (Sherwood, 2001).

Peningkatan trigliserida dipicu oleh mengkonsumsian makanan yang mengandung lemak. Kelebihan trigliserida akan ditimbun dalam jaringan di bawah kulit sebagai cadangan energi. Proses pencernaan lemak dari makanan menghasilkan trigliserida dan lemak bebas. Semua senyawa lemak ini akan diserap oleh tubuh melalui usus ke dalam darah. Pada penderita diabetes mellitus terjadi abnormalitas metabolisme lemak. 
Aktivitas lipolisis (pemecahan lemak) tidak terkendali, menyebabkan tingginya kadar asam lemak bebas, trigliserida (hipertrigliseridaemia) dan kolesterol (hiperkolesterolemia). Hipertrigliseridemia ini ditandai dengan peningkatan trigliserida yang berasal dari VLDL dan kilomikron (Suyono, 1996). Tujuan penelitian ini adalah untuk mengetahui hubungan asupan lemak dan serat dengan kadar trigliserida pada pasien diabetes mellitus tipe II di Ruang Poli Penyakit Dalam RSUD Dr.M.Yunus Bengkulu.

\section{BAHAN DAN CARA KERJA}

Jenis penelitian ini adalah survey analitik dengan pendekatan case control. Populasi penelitian adalah pasien diabetes mellitus yang Pengumpulan data menggunakan food frequency questioner untuk mencari data tentang asupan lemak dan serat pada pasien diabetes mellitus. Analisis data menggunakan analisis univariat dan analisis bivariat dengan menggunakan Uji Korelasi. Penelitian telah dilaksanakan pada tanggal 18 Februari s.d. 1 Maret 2013.

Subjek pada penelitian ini adalah pasien yang berkunjung ke Poli Penyakit Dalam RSUD Dr.M.Yunus Bengkulu yang memenuhi kreteria. Sampel pada penelitian ini terdiri dari dua sampel kelompok yaitu: Kelompok kasus: semua pasien yang di diagnosa diabetes mellitus tipe II berjumlah 35 dengan kriteria: tercatat dalam register Poli Penyakit Dalam RSUD Dr. M.Yunus Bengkulu, bersedia menjadi sampel penelitian, responden harus memiliki data laboratorium (kadar trigliserida) selama 1 bulan terakhir. pasien dengan diagnosa medis pasien diabetes mellitus tipe ii. usia dewasa (20-65 tahun). bertempat tinggal di Bengkulu. Kelompok kontrol : semua pasien di diagnosa non diabetes mellitus yang menjalani berbanding 1:1 dengan kriteria : tercatat dalam register di Poli Penyakit Dalam RSUD Dr. M.Yunus Bengkulu, bersedia menjadi sampel penelitian, responden harus memiliki data laboratorium (kadar trigliserida) selama 1 bulan terakhir. pasien dengan diagnosa medis selain diabetes mellitus tipe II, usia dewasa
(20-65 tahun). Sampel penelitian berjumlah 70 orang yang diambil dengan teknik purposive sampling,

Jenis data yang dikumpulkan adalah data primer dan skunder. Data primer yang dikumpulkan meliputi: identitas pasien, riwayat nutrisi dan riwayat penyakit pasien diperoleh dari wawancara dan data pencatatan langsung yaitu asupan makanan pasien dengan metode food frequency ( $F F Q$ ) semi kuantitatif. Data sekunder: Diperoleh dari hasil Medical record dan data hasil laboratorium yaitu kadar trigliserida pasien diabetes mellitus tipe II RSUD Dr. M.Yunus Bengkulu.Pengambilan data dilakukan dengan menggunakan lembar pedoman Food Frequency Quesioner (FFQ) dengan metode wawancara. Hasil Food Frequency Quesionery semi kuantitatif diolah dengan menggunakan program Nutrisurvey. Analisis bivariat dilakukan untuk mengetahui hubungan anatara variabel independen (asupan lemak dan serat) dan variabel dependen (kadar trigliserida) dengan hubungan kolerasi pearson.

\section{HASIL}

\section{Karakteristik Responden}

Analisis univariat dilakukan untuk mendeskripsikan (menggambarkan) karakteristik masing-masing variabel yang diteliti, baik variabel bebas (asupan lemak dan serat) maupun variabel terikat (kadar trigliserida. Adapun hasil analisisnya sebagai berikut :

Tabel 1 Distribusi Karakteristik Pasien Diabetes Mellitus dan Non Diabetes Mellitus di Poli Penyakit Dalam RSUD Dr. M. Yunus Bengkulu

\begin{tabular}{lcccc}
\hline \multirow{2}{*}{ Variabel } & \multicolumn{2}{c}{ DM } & \multicolumn{2}{c}{ Non DM } \\
\cline { 2 - 5 } & n & \% & n & \% \\
\hline Umur : & & & & \\
$\leq 40$ tahun & 3 & 8,6 & 8 & 22,9 \\
$>$ 40 tahun & 32 & 91.4 & 27 & 77,1 \\
Jenis kelamin : & & & & \\
Laki-laki & 13 & 37,1 & 13 & 37,1 \\
Perempuan & 22 & 62,9 & 22 & 62,9 \\
\hline
\end{tabular}


Berdasarkan tabel 4.1 menggambarkan bahwa sebagian besar umur pasien diabetes mellitus dan non diabetes mellitus adalah > 40 tahun. Sedangkan untuk jenis kelamin pasien sebagian besar adalah berjenis kelamin perempuan.

Tabel 2 Distribusi Frekuensi Asupan Lemak, Serat dan Kadar Trigliserida pada Pasien Diabetes Mellitus dan non Diabetes Mellitus di Poli Penyakit Dalam RSUD Dr. M. Yunus Bengkulu

\begin{tabular}{|c|c|c|c|c|c|}
\hline Variabel & Mean & Median & SD & Min & Maks \\
\hline \multicolumn{6}{|c|}{ Diabetes Mellitus } \\
\hline $\begin{array}{l}\text { Asupan } \\
\text { Lemak (gr) }\end{array}$ & 61,4 & 60,900 & 10,985 & 39,80 & 87,30 \\
\hline $\begin{array}{l}\text { Asupan Serat } \\
\text { (gr) }\end{array}$ & 7,9 & 7,90 & 1,66 & 4,50 & 10,80 \\
\hline $\begin{array}{l}\text { Kadar } \\
\text { Trigliserida } \\
(\mathrm{mg} / \mathrm{dL})\end{array}$ & 151,8 & 142,00 & 54,93 & 72 & 279 \\
\hline \multicolumn{6}{|c|}{ Non Diabetes Mellitus } \\
\hline $\begin{array}{l}\text { Asupan } \\
\text { Lemak (gr) }\end{array}$ & 57,3 & 59,30 & 10,723 & 33,10 & 71,00 \\
\hline $\begin{array}{l}\text { Asupan } \\
\text { Serat (gr) }\end{array}$ & 8,2 & 7,80 & 1,74 & 4,90 & 12,70 \\
\hline $\begin{array}{l}\text { Kadar } \\
\text { Trigliserida } \\
(\mathrm{mg} / \mathrm{dL})\end{array}$ & 134,1 & 121,00 & 50,227 & 68 & 249 \\
\hline
\end{tabular}

Tabel 2 didapatkan hasil bahwa ratarata asupan lemak makanan pasien diabetes mellitus adalah $61,4 \mathrm{gr}$, bila dibandingkan dengan asupan lemak yang dianjurkan, ratarata asupan lemak pasien diabetes mellitus adalah tinggi ( $25 \%$ atau 55 gr). Rata-rata asupan serat makanan pasien diabetes mellitus adalah 7,9 gr, bila dibandingkan dengan asupan serat yang dianjurkan, rata-rata asupan serat pasien diabetes mellitus adalah rendah (25-35 gr/hr). Rata-rata kadar trigliserida pasien diabetes mellitus adalah 151,8 $\mathrm{mg} / \mathrm{dL}$, dibandingkan dengan kadar trigliserida normal $(<150 \mathrm{mg} / \mathrm{dL})$, rata-rata kadar trigliserida pada pasien diabetes mellitus adalah tinggi.

Hasil pada tabel 2 juga didapatkan hasil bahwa rata-rata asupan lemak makanan pasien non diabetes mellitus adalah 57,3 gr. Rata-rata asupan serat makanan pasien non diabetes mellitus adalah 8,2 gr, bila disbandingkan dengan asupan serat yang dianjur- kan, maka rata-rata asupan serat pasien non diabetes mellitus adalah rendah (25-35 $\mathrm{gr} / \mathrm{hr}$ ). Rata-rata kadar trigliserida pasien non diabetes mellitus adalah $134,1 \mathrm{mg} / \mathrm{Dl}$, dibandingkan dengan kadar trigliserida normal $(<150 \mathrm{mg} / \mathrm{dL})$, rata-rata kadar trigliserida pasien non diabetes mellitus adalah rendah.

\section{Analisis Bivariat}

Tabel 3 Hubungan Asupan Lemak dan Serat dengan Kadar Trigliserida pada Pasien Diabetes Mellitus di Poli Penyakit Dalam RSUD Dr. M. Yunus Bengkulu

\begin{tabular}{lcccccc}
\hline & \multicolumn{3}{c}{ DM } & \multicolumn{4}{c}{ Non DM } \\
\cline { 2 - 7 } Variabel & $\mathbf{n}$ & $\begin{array}{c}\text { Nilai } \boldsymbol{r} \\
\text { Pearson } \\
\text { correlation }\end{array}$ & $\boldsymbol{\rho}$ & $\mathbf{n}$ & $\begin{array}{c}\text { Nilai } \boldsymbol{r} \\
\text { Pearson } \\
\text { correlation }\end{array}$ & $\boldsymbol{\rho}$ \\
\hline Asupan & 35 & 0,497 & 0,002 & 35 & 0,461 & 0,005 \\
$\begin{array}{l}\text { Lemak } \\
\text { dengan }\end{array}$ & & & & & \\
$\begin{array}{l}\text { Kadar } \\
\text { Trigliserida }\end{array}$ & & & & & \\
Asupan & 35 & $-0,041$ & 0,813 & 35 & $-0,256$ & 0,138 \\
$\begin{array}{l}\text { Serat } \\
\text { dengan }\end{array}$ & & & & & \\
Kadar & & & & & \\
Trigliserida & & & & & \\
\hline
\end{tabular}

Tabel 3 menunjukkan bahwa terdapat hubungan positif antara asupan lemak makanan dengan kadar trigliserida $(\rho=0,002<\alpha$ $=0,05)$. Sedangkan hubungan antara asupan serat dengan kadar trigliserida menunjukkan hubungan yang lemah dan berpola negatif ($0,041)$, artinya semakin tinggi asupan serat semakin rendah kadar trigliserida. Dari hasil uji statistik didapatkan tidak ada hubungan yang bermakna $(\rho=0,813>\alpha=0,05)$.

Pada tabel 3 menunjukkan bahwa pada pasien non diabetes mellitus, hubungan antara asupan lemak makanan dengan kadar trigliserida menunjukkan hubungan yang sedang dan berpola positif $(0,461)$, artinya semakin tinggi asupan lemak makanan semakin tinggi kadar trigliserida. Dari hasil uji statistik didapatkan ada hubungan yang bermakna, hal ini ditunjukkan oleh $\rho=0,005<$ $\alpha=0,05$. Sedangkan hubungan antara asupan serat dengan kadar trigliserida menunjukkan hubungan yang lemah dan berpola negatif (- 
0,256), artinya semakin tinggi asupan serat semakin rendah kadar trigliserida. Dari hasil uji statistik didapatkan tidak ada hubungan yang bermakna, hal ini ditunjukkan oleh $\rho=0,138>\alpha=0,05$.

\section{PEMBAHASAN}

\section{Hubungan Asupan Lemak dengan Kadar Tri-gliserida}

Asupan lemak yang tinggi dapat meningkatkan kadar trigliserida dalam darah. Dari hasil penelitian menunjukkan bahwa ratarata kadar trigliserida pada pasien diabetes mellitus di RSUD Dr. M. Yunus Bengkulu yaitu $151,8 \mathrm{mg} / \mathrm{dL}$ dengan kadar trigliserida terendah adalah $72 \mathrm{mg} / \mathrm{dL}$ dan kadar trigliserida tertinggi adalah $279 \mathrm{mg} / \mathrm{dL}$. Sedangkan rata-rata kadar trigliserida pasien non diabetes mellitus yaitu $134,1 \mathrm{mg} / \mathrm{dL}$. Bila dibandingkan dengan kadar trigliserida normal, yaitu $<150 \mathrm{mg} / \mathrm{dL}$ maka rata-rata kadar trigliserida tinggi.

Sedangkan rata-rata asupan lemak pada pasien diabetes mellitus adalah 61,4 gr. Sedangkan rata-rata pasien non diabetes mellitus adalah 57,3 gr. Hal ini menunjukkan bahwa asupan lemak pasien diabtes mellitus lebih tinggi dari jumlah asupan lemak yang dianjurkan yaitu $15-25 \%$ atau 55 gr/hari dari kebutuhan energi. Dari hasil FFQ semi kuantitatif dapat diketahui bahwa kelebihan asupan lemak disebabkan karena responden sering mengkonsumsi makanan sumber lemak seperti lemak, daging ayam, daging sapi, santan dan minyak goreng.

Lemak yang terdapat dalam makanan terdiri dari beberapa jenis asam lemak, yaitu asam lemak jenuh dan asam lemak tidak jenuh. Lemak jenuh cenderung meningkatkan kadar kolesterol dan trigliserida, yang merupakan komponen-komponen lemak dalam darah. Bahan makanan yang mengandung lemak jenuh adalah lemak hewan, lemak susu, mentega, keju, kream, santan, minyak kelapa, kue-kue dan lain-lain. Sebaliknya, lemak tidak jenuh terdiri dari lemak tidak jenuh tunggal dan lemak tidak jenuh ganda yang dapat mengurangi kadar kolesterol dan trigliserida darah. Lemak tidak je- nuh terdapat pada minyak kedelai, minyak zaitun, dan minyak ikan. Asam lemak tidak jenuh ganda dapat dikelompokkan menjadi dua yaitu asam lemak omega-6 dan omega-3 yang dapat menurunkan kadar lemak dalam darah (kolesterol dan trigliserida) dan mencegah pembekuan darah (Damanhuri, 2007).

Asam lemak omega-6 (linoleat) dan asam lemak omega -3 (linolenat) adalah asam lemak yang di butuhkan oleh tubuh untuk pertumbuhan dan fungsi normal semua jaringan, sedangkan tubuh tidak dapat mensintesisnya. Manfaat asam lemak linoleat dan linolenat ini yaitu berperan penting dalam transport dan metabolisme lemak serta fungsi imun. Asam lemak omega-3 dapat mem-bersihkan plasma dari lipoprotein kilomikron dan VLDL (very low density lipoprotein), serta menurunkan produksi trigliserida, kolesterol di dalam hati sehingga asam lemak ini dapat menurunkan kadar kolesterol total, kadar kolesterol LDL, serta dapat meningkatkan kadar kolesterol HDL.

Trigliserida merupakan jenis lemak yang ditemukan dalam darah dari hasil uraian dalam tubuh dari asupan makanan yang mengandung lemak dan kolesterol yang dibentuk di hati. Trigliserida yang ada didalam hati ditransport oleh lipoprotein ke jaringan adiposa, dimana trigliserida juga disimpan untuk energi (Arthur C. Guyton, 1991).

Dari hasil bivariat dengan uji korelasi, hubungan asupan lemak dengan kadar trigliserida menunjukkan hubungan yang sedang dan berpola positif $(0,497)$, artinya semakin tinggi asupan lemak semakin tinggi kadar trigliserida. Dari hasil uji statistic didapatkan ada hubungan yang bermakna $(\rho=0,002)$.

Hasil penelitian ini sejalan deangan hasil penelitian yang dilakukan oleh Elok Faekoh (2003) tentang hubungan gula darah, tingkat konsumsi lemak, status gizi dan latihan fisik pada pasien diabetes mellitus. Didapatkan ada hubungan antara tingkat konsumsi lemak dengan kadar trigliserida.

Trigliserida yang berlebihan dalam tubuh dapat menimbulkan berbagai masalah kesehatan. Tingginya kadar trigliserida darah berisiko penyakit jantung khususnya diabetes mellitus. Konsumsi makanan berlemak 
yang berlebihan dan aktivitas fisik yang kurang dapat memicu kegemukan dan meningkatkan kadar trigliserida (Ramadhan, 2009).

Konsumsi lemak dapat meningkatkan kadar trigliserida darah, peningkatan kadar trigliserida tidak hanya dari asupan lemak saja, tetapi dari faktor lain seperti asupan zat gizi lain (karbohidrat), olahraga, umur dan keteraturan minum obat.

\section{Hubungan Asupan Serat dengan Kadar Trigli-serida}

Hasil penelitian menunjukkan bahwa rata-rata kadar trigliserida pada pasien diabetes mellitus di RSUD Dr. M. Yunus Bengkulu yaitu $151,8 \mathrm{mg} / \mathrm{dL}$ dengan kadar trigliserida terendah $72 \mathrm{mg} / \mathrm{dL}$ dan kadar trigliserida tertinggi $279 \mathrm{mg} / \mathrm{dL}$. Sedangkan ratarata kadar trigliserida pada pasien non diabetes mellitus adalah $134,1 \mathrm{mg} / \mathrm{dL}$.

Rata-rata asupan serat pasien diabetes mellitus RSUD Dr. M. Yunus Bengkulu yaitu 7,9 gr, sedangkan rata-rata asupan serat pasien non diabetes mellitus adalah 8,2 gr. Hal ini menunjukkan bahwa asupan serat pasien diabetes mellitus kurang dari jumlah asupan serat yang dianjurkan yaitu $\geq 25$ gr/hari. Ini disebabkan rata-rata responden kurang mengkonsumsi makanan mengandung serat, dilihat dari analisis Food Frequency Quesioner semi kuantitatif pada pasien diabetes mellitus sangat rendah karena dalam penelitian ini hanya dianalisis secara umum, tidak menganalisis serat secara spesifik seperti serat kasar dan serat terlarut, sehingga menyebabkan rata-rata asupan serat rendah. Oleh karena itu dianjurkan untuk lebih banyak mengkonsumsi makanan yang mengandung serat (fiber).

Serat ditemukan dalam buah-buahan, sayur-sayuran serta beberapa jenis kacangkacangan dan beberapa biji-bijian seperti oat, rye, barley. Serat tersebut terlarut dan membentuk gel dalam air. Bentuk gel ini dalam saluran pencernaan menyebabkan kecepatan melambat dalam mendorong komponen makanan ke usus. Di dalam saluran pencernaan harus tersedia asam empedu supaya system metabolisme lemak tidak terganggu, yang berperan dalam mengemulsi lemak seperti trigliserida sehingga terurai menjadi asam lemak yang akan diserap tubuh (Koswara, 2009).

Rata-rata asupan serat pasien diabetes mellitus dibawah asupan serat normal, sehingga didapat hubungan asupan serat dengan kadar trigliserida menunjukkan hubungan yang lemah dengan berpola negatif $(-0,041)$, artinya semakin tinggi asupan serat semakin rendah kadar trigliserida.

Pada penelitian ini hasil analisis bivariat dengan uji korelasi didapatkan tidak ada hubungan yang bermakna, hal ini ditunjukkan $\rho=0,813>\alpha=0,05$. Hal ini bisa saja disebabkan sampel peneliti yang masih kurang besar untuk membuktikan hasil uji, berdasarkan hasil Food Frequency Quesioner rata-rata asupan serat responden kurang dari asupan serat yang dianjurkan 25 -35 gr/hari sehingga sulit untuk mengabsorbsi kadar trigliserida dalam darah.

Pada penelitian ini terdapat beberapa kelemahan yang mempengaruhi hasil dari penelitian yaitu dari metode survey konsumsi makanan yang digunakan untuk mengumpulkan data yaitu metode Food Frequency Quesioner semi kuantitatif yang mempunyai kelemahan bias akan hasil, hal ini diakibatkan oleh berbagai faktor seperti sulitnya menentukan takaran yang pasti untuk jumlah dan frekuensi setiap jenis makanan yang dikonsumsi responden, memerlukan ingatan yang kuat dan cukup menjenuhkan bagi responden.

Metode FFQ semi kuantitatif ini lebih dibuat sedemikian rupa untuk menggali pola kebiasaan konsumsi responden, namun karena umur responden yang lebih banyak diatas 40 tahun yaitu sebanyak 59 orang dari total responden 70 orang responden, sehingga daya ingat mereka akan makanan yang dikomsumsi dan jumlahnya selama satu tahun terakhir ini sulit didapatkan secara pasti, selain ituresponden juga kurang motivasi sehingga mempengaruhi hasil wawancara yang dilakukan, tidak jarang terjadi the flat slope sundrome, dimana responden hanya mereka yang sering makanan yang sering dikonsumsi, bahkan tidak jarang mengurangi atau 
menambahkan ketika diwawancarai. Kurang pastinya ukuran rumah tangga yang disebutkan responden, maka hal ini juga berdampak pada pengestimasian berat dan jumlah makan yang dikonsumsi.

\section{KESIMPULAN}

Hasil penelitian menyimpulkan bahwa rata-rata asupan lemak pada pasien diabetes mellitus di RSUD dr. M. Yunus Bengkulu

\section{DAFTAR RUJUKAN}

Achmadi, Endang L 2007, Gizi dan Kesehatan Masyarakat Departemen Gizi dan Kesehatan Masyarakat FKMUI, Rajawali Grafindo Persada, Jakarta.

Adam, J., 2006. Buku Ajar Ilmu Penyakit Dalam. Edisi IV Jilid III. Jakarat: Pusat Penerbitan Departemen Ilmu Penyakit Dalam Fakultas Kedokteran Universitas Indonesia.

Almatsier, Sunita. 2002. Prinsip Dasar Ilmu Gizi. Gramedia Pustaka Utama. Jakarta.

Almatsier, Sunita. 2003. Prinsip Dasar Ilmu Gizi. Gramedia Pustaka Utama. Jakarta.

Almatsier, Sunita. 2006. Penuntun Diet. Gramedia Pustaka Utama. Jakarta.

Almatsier, S. (2009). Prinsip Dasar Ilmu Gizi. Jakarta : Penerbit PT Gramedia Pustaka Utama.

American Diabetes Association, 2003. Diagnosis and Classification of Diabetes Mellitus. Diabetes Care Vol.33: 562-569.

Anna Poedjiadi,Dkk, 2005,Dasar-dasar Biokimia, Universitas Indonesia, (UI-Press). Jakarta

Arthur C. Guyton. 1991. Buku Teks Fisiologi Kedokteran. Alih Bahasa Adji Dharmadan P. Lukmanto. Jakarta : EGC.

Brown. K.H, Dewey. K.G, Allen. L.H. 2004. Complementary Feeding of Young Children in Developing Countries : A Review of Current Scientific Knowledge, WHO/NUT/98.1. Geneva. Food and Nutrition Bulletin Vol 25 No 1 March 2004. Supplement 2

Depkes RI. Profil kesehatan Indonesia 2001 Menuju Indonesia sehat 2010. Jakarta: Departemen Kesehatan RI. 2002:40.

Depkes RI, 2009. Sistem Kesehatan Nasional. Jakarta.

Departemen Gizi dan Kesehatan Masyarakat. 2007. Gizi dan Kesehatan Masyarakat. FKMUI. Rajawali Grafindo Persada. Jakarta.

Jalal, F. 2006. Hubungan Lingkar Pinggang terhadap Kadar Trigliserida Darah dan Tekanan Darah. Universitas Andalas. Sumatera Barat. adalah tinggi $(61,4 \mathrm{~g})$, rata-rata asupan serat adalah rendah $(7,9 \mathrm{~g})$, dan rata-rata kadar trigliserida adalah normal $(151,8 \mathrm{mg} / \mathrm{dL})$ serta ada hubungan yang bermakna antara asupan lemak dengan kadar trigliserida $(\rho=0.002)$. Disarankan kepada ahli gizi dapat memberikan penyuluhan secara berkala dengan menggunakan leaflet mengenai asupan lemak dan serat.

Komsan, A. 2004. Pangan dan Gizi untuk Kesehatan. Rajagrafindo Persada. Jakarta.

Koswara. 2009. Teknologi Pengolahan Jagung (Teori dan Praktek). eBook Pangan.com

Linder, Maria C. 1992. Biokimia Nutrisi dan Metabolisme dengan Pemakaian Secara Klinis. Jakarta: Penerbit Universitas Indonesia.

Mayes, Peter A. 2003 C .Glukoneogenesis dan Pengontrolan Kadar Glukosa Darah .

In: Murray, R.K., Granner, D.K., Mayes, P.A., dan Rodwell, V.W., eds. Biokimia Harper. Edisi ke25. Jakarta: EGC. 195-205.

Moehji, Sjahmein. 2009. ILMU GIZI (Pengetahuan Dasar Ilmu Gizi) Cetakan ke 3 Papas Sinar Sinanti.

Muray, R.K dkk. 2003. Biokimia Harper edisi 25. Buku Kedokteran EGC Jakarta.

Notoatmodjo, S. 2005. Metodologi Penelitian Kesehatan. Rineka Cipta, Jakarta.

Powers, A.C., 2005. Diabetes Mellitus. In : Gibson, R.J., ed. The 16th Edition Of

Harrison's Principles Of Internal Medicine. USA: The McGraw-Hill Companies, 2152-2171.

Sandjaja. 2009. Kamus Gizi Pelengkap Kesehatan Keluarga. Kompas. Jakarta.

Sandjaja dkk. 2010. Kamus Gizi Pelengkap Kesehatan Keluarga. Cetakan ke 2. Kompas. Jakarta.

Sediaoetama Djaeni, A. 2008. Ilmu Gizi Jilid I. Dian Rakyat. Jakarta.

Sherwood, L. 2001. Fisiologi Manusia dari Sel ke Sistem. Edisi 2. Jakarta;EG

Soegondo, S, Gustaviani, R .2005. Sindrom Metabolik. Buku Ajar Ilmu Penyakit Dalam Jilid III

Soeharto, Iman. 2004. Serangan Jantung Dan Stroke, Hubungannya dengan Lemak Dan Kolesterol. Edisi Kedua. PT Gramedia Pustaka, Jakarta

Sofia, Sara. 2009. Hubungan indeks massa tubuh dengan kadar kolesterol, trigliserida dan gula darah puasa pada pasien diabetes mellitus. FKMUI. Jakarta 
Sulistijiani, A. 2005. Sehat Dengan Menu Berserat. Pustaka Perkembangan Swadaya Nusantara. Jakarta.

Supariasa. (2001). Gizi dalam Masyarakat. Jakarta: PT. Elex Media

Suyono, Slamet. 1996. Hiperlipidemia dalam Ilmu Penyakit. Gaya Baru. Jakarta

Suyono, Slamet. 2006. Diabetes Mellitus di Indonesia. Dalam Ilmu Penyakit Dalam Jilid III.Edisi Keempat. Jakarta : Pusat Penerbitan Departemen Ilmu Penyakit Dalam Fakultas Kedokteran Universitas Indonesia, hal 1874-1875.
Tirtawinata, Tien.Ch. 2006. Makanan dan Presfektif Al-Quran dan Ilmu Gizi. FKUI. Jakarta.

Tjokroprawiro, Askandar.1998. Hidup Sehat dan Bahagia Bersama Diabetes. Edisi 2. Jakarta : Gramedia

Tjokoprawiro, Askandar. 2001. Klasifikasi diabetes mellitus. Diabetes mellitus :

Klasifikasi. diagnosis dan terapi. Edisi III. Jakarta: PT Gramedia Pustaka Utama. p. 1- 6

Tjokroprawiro, Askandar. 2002. Diabetes millitus Klasifikasi Diagnosis dan

Terapi, Edisi ketiga PT Gramedia Pustaka Utama. Jakarta 